\title{
Fula Language
}

National Cancer Institute

\section{Source}

National Cancer Institute. Fula Language. NCI Thesaurus. Code C153924.

A Niger-Congo language spoken as a set of various dialects in a continuum that stretches across 20 countries in West and Central Africa. 